\title{
ALKALINE LAKE SYSTEM IN DANUBE AND TISZA INTERFLUVE (SZEGED, HU) - CLIMATE CHANGE AND LANDSCAPE DEGRADATION
}

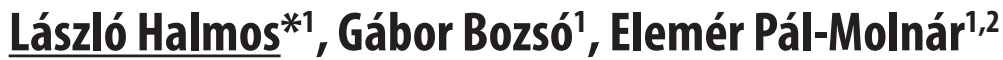 \\ 'University of Szeged, Szeged, Hungary \\ ${ }^{2}$ MTA-ELTE Volcanology Research Group, Budapest, Hungary
}

\begin{abstract}
Sodic areas can be found in every continent. The main condition of the salt accumulation in sodic soils is the near-surface groundwater. There is a serious environmental problem in the Danube-Tisza Interfluve which threatens the natural alkaline lakes and sodic areas with landscape destruction. The aim of this study is to collect information about the seasonal geochemical cycles in the sediments of Lake Fehér. Based on the results of this research, the protection of the similar alkaline wetlands could be more effective. The study area was an alkaline lake system sorrounded by sodic areas called Lake Fehér by Szeged. The investigation was carried out in three periods based on the seasonal distribution of precipitation. There were eight sampling dates on the same site during one meteorological year. For the short-term monitoring, the type of the soil, the particle content, the $\mathrm{pH}$ and the EC were investigated. The groundwater and precipitation data of the last century were used for the long-term observation. The results show that the precipitation decreased in the southern part of the Danube-Tisza Interfluve in the last 100 years. Along with the decreasing precipitation, the groundwater level has been sinking. Knowing the dynamics of the area, the problem could be managed; otherwise, the ecosystems of the alkaline lakes will vanish.
\end{abstract}

Keywords: precipitation, groundwater, $\mathrm{pH}, \mathrm{EC}$

\section{Introduction}

There are sodic areas on every continent. The common effect of climatic and hydrogeological processes is necessary for their formation. The basis of the salinization process is the accumulation of $\mathrm{Na}^{+}$salts in near-surface levels of the soils that causes the degradation of the soil structure (Bohn et al., 1985; McBride, 1994).

The alkaline lakes are a distinctive group in the category of still waters based on their chemical properties of water. The largest alkaline lakes - that are literally lakes - are the Lake Velencei and Lake Fertő in Hungary. The term alkaline lake also indicates such wetland that is concerned by salinization but there is only periodical water coverage on the area (Boros, 2002).

Most alkaline lakes have special importance for nature conservation because they have unique and specialized flora and fauna. The great part of these wetlands is protected by NATURA 2000 regulation (Stanová et al., 2008).

The alkaline lakes are threatened by serious environmental problems in the Danube and Tisza Interfluve (Szilágyi and Vorosmarty, 1993; Pálfai, 1994). The inland drainage has been causing changes in the ecosystem of the alkaline lakes since the $19^{\text {th }}$ century, but the real harm is the extraction of groundwater resources (Boros, 2010). The main driving force of the salinization is the near-surface groundwater but the groundwater level is sinking in the Danube and Tisza Interfluve and this phenomenon causes the degradation of natural sodic areas (Rakonczai and Bódis 2002; Tóth, 2005). The problem is exacerbated by the climate change because of the precipitation deficit in this area (Rakonczai et al. 2008; D'0dorico et al., 2013). The refilling of the alkaline lakes lags behind in autumn and spring and the groundwater resources cannot be replenished because of the uneven distribution of precipitation. As the salinization process stops, the leaching starts and the previous sodic area is transformed to steppe.
The most sufficient area for this study was Lake Fehér near Szeged, which is a typical alkaline lake system in the Danube and Tisza Interfluve. The appellation Lake Fehér represents the totality of connected but separated lakes and most of them are operating as fishponds today, and the remaining parts are nature reserves. The total water surface is $14 \mathrm{~km} 2$ and the catchment area is $200 \mathrm{~km} 2$. The study area lies in the northwest direction, $9 \mathrm{~km}$ away from Szeged. The sampling point is located to the northwest direction from the larger lakes (Figure 1). Lake Fehér was formed with salinization of deflationary depressions. Keveiné et al. (2000) explained the formation of the lake system with the wind erosion. Lake Fehér was located in north compared to the current location based on the sedimentological investigation (Molnár, 1996), and with the permanent new-Holocene grit blasting, it was shifted to south-southeast.

This study presents the environmental problems of the Danube-Tisza Interfluve through short- and long-term observations. The aim of this study is to get to know the seasonal hydrological and geochemical cycles of the sediments in Lake Fehér, so that based on our results, the protection of the similar alkaline wetlands could be more effective.

\section{Materials and methods}

The precipitation data are the most important ones from the meteorological datasets because of the water balance, which plays crucial role in salinization. The precipitation data of Szeged were downloaded from the OMSZ homepage (www.met.hu). The graph of the annual precipitation averages and the monthly averages was made to represent the changing amount and distribution of precipitation in the last century (Figure 2).

The data of groundwater regime are originated from two wells, that are the nearest to the study area. The identifiers of the wells are 2408 Szatymaz and 2413 Sándorfalva (Figure 1 and Figure 3) (ATIVIZIG). 

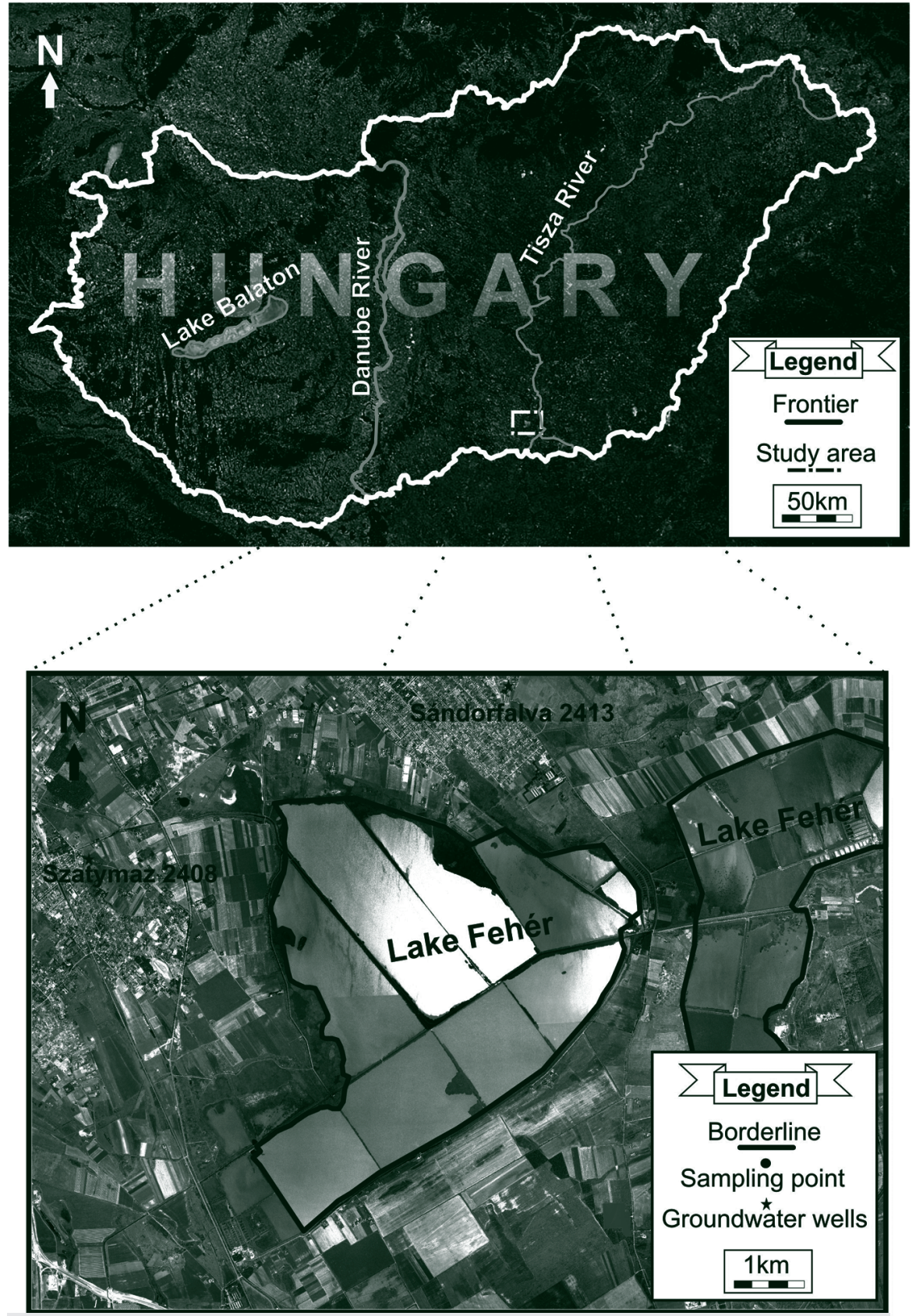

Figure 1 The study area with the sampling point and groundwater wells

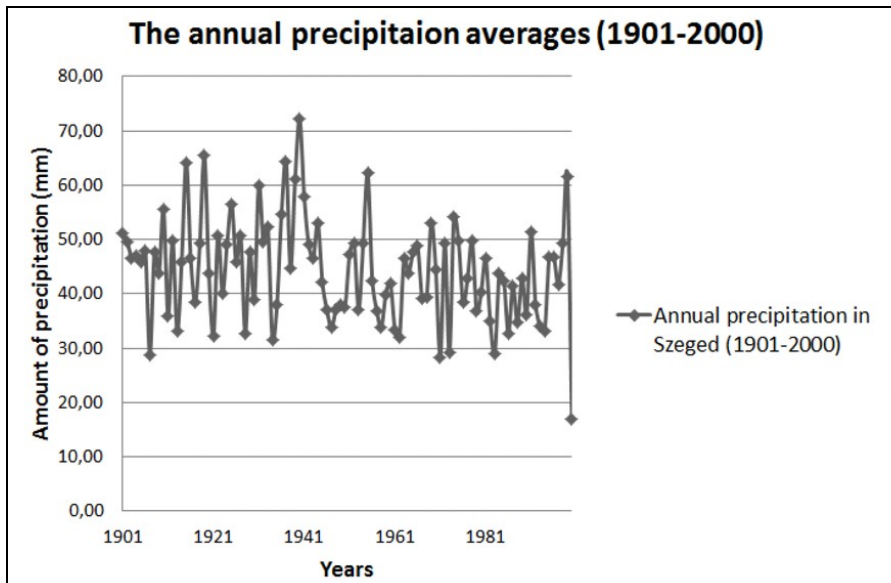

The samplings were carried out in 3 periods; 3 times in the summer of 2012, 2 times in the autumn, then 3 times in the spring of 2013. The sampling dates were designated based on the monthly averages of precipitation of the last century. The sediment cores were taken out with gimlet and the depth of these columns was $1 \mathrm{~m}$ with $10 \mathrm{~cm}$ diameter. After the columns were pulled out and taken to a laboratory, their weight was measured and dried out in $20 \mathrm{~cm}$ pieces. The weigh measurement was repeated on the dry samples, so the water content was evaluated.

The particle size examination of the first whole sediment core was made with Laser Particle Sizer analysette 22 instruments in $0.1-2,000 \mu \mathrm{m}$ size range. The subsamples were taken from every $5 \mathrm{~cm}$ of the column in the upper $50 \mathrm{~cm}$, then every $10 \mathrm{~cm}$ in the $50-100 \mathrm{~cm}$ range.

Suspensions were made after grinding the half of every sediment sample. The ratio of suspensions was $1: 2.5$ (sediment - distilled water) properly to the Hungarian Standard (MSZ 21470/2-81, 1982). The pH measurement was conducted with CONSORT C561 type instrument and with WTW SenTix 52 type combined electrode. The EC measurement was carried out from the same suspension and the same instrument was used with SENTEK electrode. The $40 \mathrm{pH}$ and $40 \mathrm{EC}$ measurements were all carried out.

\section{Results and discussion}

The water has a decisive role in the salinization process (Bozsó et al., 2008; Pál-Molnár and Bozsó, 2008; Boros, 1999; Tóth, 2005), and that is why the precipitation is such an important factor in the investigation of sodic areas. On the base of the analysis of the monthly averages of 100 years precipitation data, it appears that there are two maximums of the precipitation in a year in Szeged (Figure 2). The first maximum

Figure 2 The annual and monthly precipitation averages in Szeged (1901-2000) 


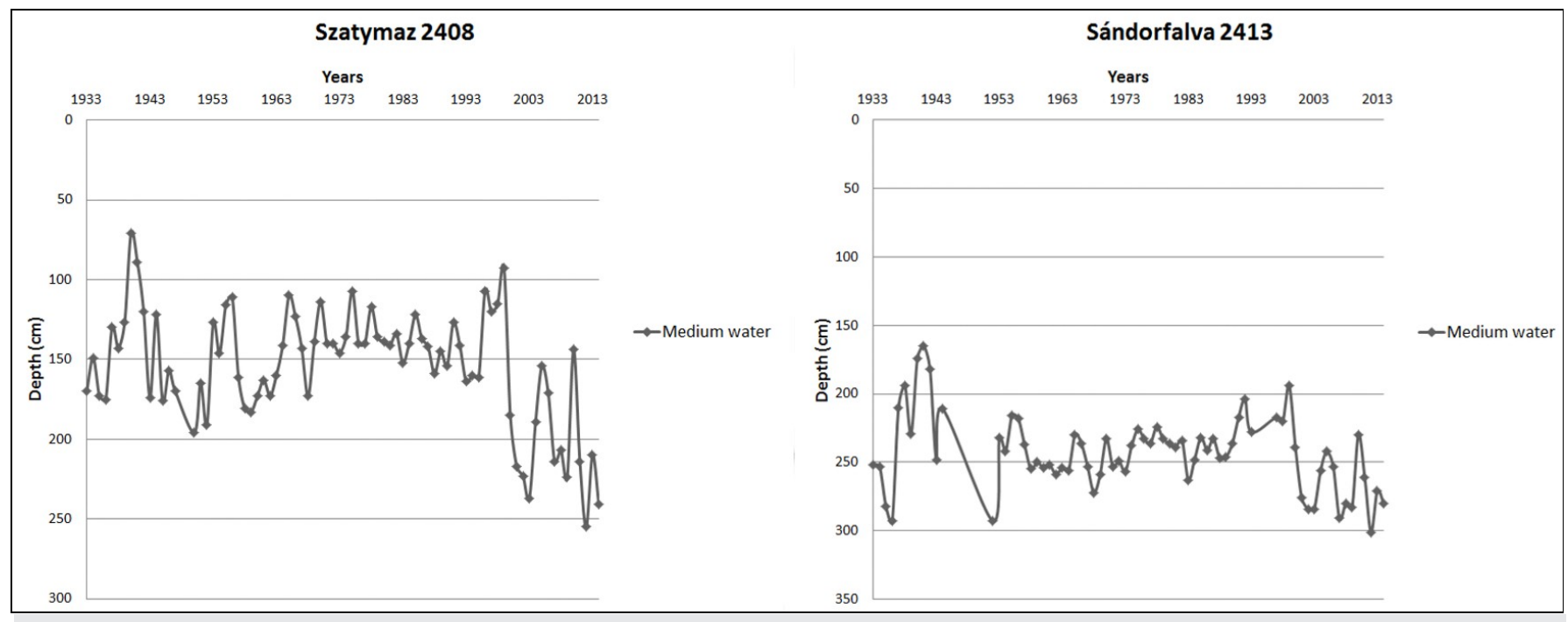

Figure 3 The groundwater level in the investigated wells since 1933

is in the summer between May and July and the second maximum is formed during autumn because of the intensifying cyclone activity. The least amount of precipitation is between January and March (Péczely, 2009). Between 1901 and 2000, the 100 year average of precipitation dataset shows the decreasing tendency in Szeged and even in the wider environment (Figure 2).

The used data of groundwater level are originated from two wells, which are the closest ones to the study area, as mentioned above (ATIVIZIG) (Figure 1). The ground-water level changing has been registered in the wells since 1933 (Figure 3). Significant decreasing is observed in the annual medium water data of the last 80 years in these wells as well as in the whole southern part of the Danube-Tisza Interfluve (Figure 3). The reasons of the decreasing groundwater are not only the climate elements, but the anthropogenic activity like the water management in the $19^{\text {th }}$ century and the water extraction for agriculture usage (Várallyay, 1999). The average level of the groundwater changes in $200-300 \mathrm{~cm}$ depth in the area. The amount of the groundwater decreases during the summer hydrological half-year (from the end of April to the end of October) and increases during the winter hydrological half-year (from the end of October to the end of April) (Nyizsalovszki and Szabó, 2003).

The analysis of the drill cores started with macroscopic description and determination of the soil type. The colour of the soil is dark greyish near to the ground surface, but it is getting lighter gradually with the depth. At the depth of $60 \mathrm{~cm}$, the colour of the soil changes yellowish and this tinge becomes pale with the depth. The first $60 \mathrm{~cm}$ (from the ground surface) of the soil column is characterized by crop residues and lime concretions. In the depth range of $60-80 \mathrm{~cm}$, the soil is limonitic. There are mollusc shells from 40 to $100 \mathrm{~cm}$ depth in the samples. In the level B there is salt accumulation and humification. The motion of solutions in the soil is periodic. Based on these features and the depth of the groundwater level, this soil is gleyic salic calcic solonetz siltic (WRB, 2007).

The upper $15 \mathrm{~cm}$ of the soil has the highest sand content based on the particle analysis (Table 1). The amount of clay fraction is the lowest in this

Table 1 Particle fractions in the sediment samples of Lake Fehér, Szeged

\begin{tabular}{|c|c|c|c|c|c|c|c|c|c|c|c|c|c|c|c|}
\hline \multirow[b]{2}{*}{ Particle size in $\mu m$} & $\begin{array}{l}E \\
\tilde{o} \\
\grave{o}\end{array}$ & $\frac{E}{5}$ & $\begin{array}{l}E \\
\stackrel{0}{0} \\
\text { ஸे }\end{array}$ & 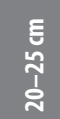 & $\begin{array}{l}E \\
0 \\
1 \\
\vdots\end{array}$ & $\begin{array}{l}E \\
\text { ñ } \\
0 \\
\text { ô }\end{array}$ & $\begin{array}{l}E \\
8 \\
\\
\text { L }\end{array}$ & $\begin{array}{l}E \\
\qquad \\
1 \\
8\end{array}$ & $\begin{array}{l}\Xi \\
0 \\
1 \\
1 \\
8\end{array}$ & $\begin{array}{l}\text { E } \\
\text { ñ } \\
\text { மீ }\end{array}$ & $\begin{array}{l}E \\
8 \\
1 \\
\kappa\end{array}$ & $\begin{array}{l}E \\
8 \\
1 \\
0 \\
0\end{array}$ & $\begin{array}{l}E \\
\delta \\
1 \\
1\end{array}$ & $\begin{array}{l}\text { E } \\
8 \\
1 \\
\infty\end{array}$ & 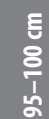 \\
\hline & \multicolumn{15}{|c|}{ Quantity of the particle fractions in \% } \\
\hline Fine clay (0.977-) & 1.8 & 2.2 & 2.5 & 7.1 & 6.5 & 4 & 8.3 & 4.1 & 6.6 & 6 & 5.2 & 5.8 & 5.5 & 5.6 & 5.5 \\
\hline Medium clay (1.95-9.77) & 2.3 & 2.5 & 3.9 & 7.4 & 6.9 & 6.6 & 10.3 & 6.5 & 9.1 & 8.6 & 8.4 & 10 & 8.5 & 9.8 & 9.3 \\
\hline Coarse clay (3.91-1.95) & 3.1 & 3.2 & 5.9 & 9.6 & 9 & 10.5 & 14 & 9.6 & 13.2 & 12.6 & 13 & 15.2 & 12 & 15 & 14.6 \\
\hline Very fine silt (7.81-3.91) & 3.3 & 3.4 & 7.1 & 11.6 & 9.5 & 11.8 & 15.2 & 10.7 & 15.1 & 11.9 & 13.7 & 16.2 & 11.5 & 14.5 & 16.8 \\
\hline Fine silt (15.6-7.81) & 5.8 & 4.8 & 12.7 & 23.4 & 18.3 & 20.9 & 20.2 & 17.5 & 19.8 & 15.7 & 18.4 & 23.1 & 18.6 & 18.6 & 22 \\
\hline Medium silt (31.25-15.6) & 8 & 5.3 & 14.9 & 30.6 & 24.4 & 27.5 & 19 & 21.6 & 20.2 & 18.9 & 22.3 & 24 & 25.3 & 25.7 & 24.1 \\
\hline Coarse silt (62.5-31.25) & 6.3 & 4.2 & 4.2 & 10 & 10.1 & 14.2 & 10.7 & 16.9 & 13.2 & 15.2 & 15.6 & 5.7 & 14.8 & 10.5 & 7.6 \\
\hline Very fine sand (125-62.5) & 27.4 & 29.8 & 25.5 & 0.3 & 11.6 & 4.6 & 2.2 & 12.4 & 2.8 & 10.9 & 3.4 & 0 & 3.8 & 0.3 & 0 \\
\hline Fine sand (250-125) & 38.7 & 41.2 & 23 & 0 & 3.6 & 0 & 0 & 0.6 & 0 & 0.3 & 0 & 0 & 0 & 0 & 0 \\
\hline Medium sand (500-250) & 3.3 & 3.5 & 0.3 & 0 & 0 & 0 & 0 & 0 & 0 & 0 & 0 & 0 & 0 & 0 & 0 \\
\hline Coarse sand $(1,000-500)$ & 0 & 0 & 0 & 0 & 0 & 0 & 0 & 0 & 0 & 0 & 0 & 0 & 0 & 0 & 0 \\
\hline Fine gravel $(2,000-1,000)$ & 0 & 0 & 0 & 0 & 0 & 0 & 0 & 0 & 0 & 0 & 0 & 0 & 0 & 0 & 0 \\
\hline
\end{tabular}




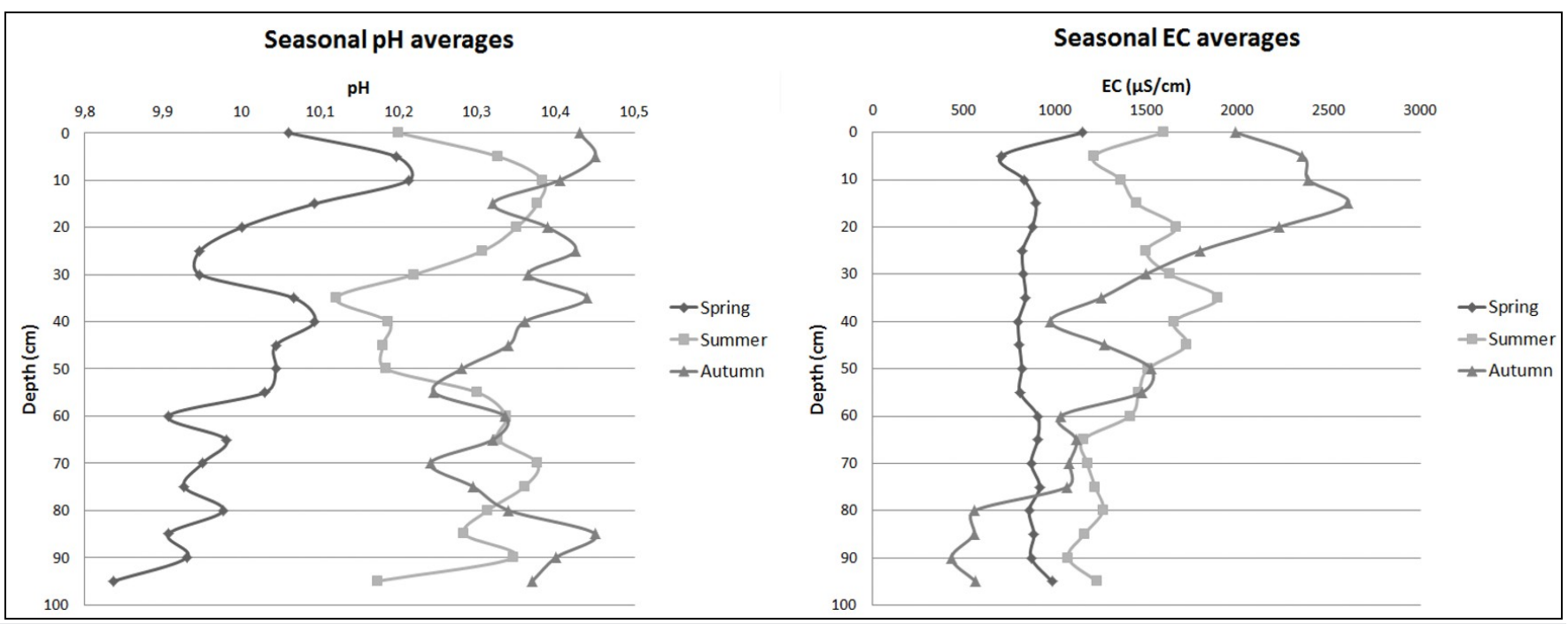

Figure 4 Seasonal pH and EC changes in the soil of Lake Fehér, Szeged

depth range. The proportions of the fractions are balanced from the $20 \mathrm{~cm}$ to the bottom of the section. This range is dominated by the silt fraction, but the amount of the clay fraction is increasing by about $20 \%$, while the proportion of the sand is decreasing. It is important to know the particle size content of the soil, because the geochemical parameters depend on physical features (Table 1).

Subsamples were taken for the $\mathrm{pH}$ measurements of every $5 \mathrm{~cm}$ from the whole $1 \mathrm{~m}$ long column. After the sample preparation - described above - the $\mathrm{pH}$ data of the suspensions were averaged according to seasons (Figure 4). The pH changed between 9.64 and 10.5. Significant differences were found in the seasonal changing in $\mathrm{pH}$. The values are the highest in autumn and the lowest in spring. The $\mathrm{pH}$ values of summer are closest to the autumn values but also show the same high deviation like in spring. The low grade deviation of the autumn $\mathrm{pH}$ data means that the distribution of the values is homogenized by geochemical processes in the whole section. The average $\mathrm{pH}$ value in the section is 10.4 in autumn.

The trends of the $\mathrm{EC}$ values are the same as the $\mathrm{pH}$ trends. In spring, the measured values are the lowest and the least diverse (Figure 4). The average of the profile is $867.85 \mu \mathrm{S} / \mathrm{cm}$ and the standard deviation is also the lowest among the other profiles. The summer EC values are over the ones measured in spring. The average of the data is $1415.85 \mu \mathrm{S} / \mathrm{cm}$ and the profile is relatively homogenous. The maximal EC value $(2606 \mu \mathrm{S} / \mathrm{cm})$ was measured in $15 \mathrm{~cm}$ depth during autumn. This means that because of the changing of the water balance and drying, the solved substances are concentrated in this level; it is an important feature of solonetz. The average of the $\mathrm{EC}$ values is lower at this time than in summer, but the deviation is nearly three times more, compared to summer.

The meaning of the described observations is that the salts of alkaline hydrolysis $\left.\left(\mathrm{CaCO}_{3}, \mathrm{MgCO}_{3}, \mathrm{Na}_{2} \mathrm{CO}_{3}, \mathrm{NaHCO}_{3}, \mathrm{Na}_{2} \mathrm{SiO}\right)_{3}\right)$ and other solved substances move upward by capillary lifting, because of the increased evaporation in spring. The higher temperature and the more precipitation are the reasons why the $\mathrm{pH}$ and the solved substances content continue in rising. In autumn, the precipitation slowly decreases but the evaporation still continues.

\section{Conclusion}

The natural form of salinization is an important landscape forming factor in the Danube and Tisza Interfluve. The ecosystem of the alkaline lakes has extraordinary specialized species that are very sensitive to the environmental change (Zhang et al., 2013).

Based on this study, it can be stated that the alkaline lakes are in serious environmental danger in the Danube and Tisza Interfluve. This danger is the water deficit, which is partly natural, and partly anthropogenic (Szilagyi and Vorosmarty, 1993).

Analysing the precipitation and groundwater data series, it seems clear that there is decreasing in both datasets in the last century. The deficit in the water balance causes the degradation of the natural sodic areas, like leaching and humification. These processes cause the appearance of the typical alkali species. There is periodical water coverage of the alkaline lakes in the Danube and Tisza Interfluve, which is negatively influenced by the negative water balance.

The precipitation is a randomly changing climate factor in which significant long-term changing could be pointed out only based on datasets of more decades. The monitoring that was carried out for a year gives information about the dynamics of sodic areas. Knowing the geochemical cycles of the observed area, the protection could be more effective in the case of the alkaline areas in the Danube-Tisza Interfluve. Based on the $\mathrm{pH}$ and $\mathrm{EC}$ datasets, the sodic feature of the areas is the strongest during summer and autumn. The refilling of the area happens from the end of autumn to the end of spring. So in the latter period, the sodic areas are the most vulnerable.

As mentioned above, the environmental problem of the Danube and Tisza Interfluve is partly natural, partly anthropogenic. The anthropogenic part of the problem could be solved with the limitation of water extraction and agricultural adaptation to the dynamics of the sodic areas. Knowing the geochemical cycles of saline lake sediments enables the agricultural adaptation.

\section{References}

BOHN, H. L. - McNEAL, B. L. - O'CONNOR, G. A. 1985. Talajkémia. Budapest : Mezőgazdasági Kiadó - Gondolat Kiadó, 1985.363 p.

BOROS, E. 1999. A magyarországi szikes tavak és vizek ökológiai értékelése. In Acta Biologica Debreciensis Oecologia Hungariae, 1999, no. 9, p. 13-80. 
BOROS, E. 2002. Szikes Tavak. In Környezetvédelmi Minisztérium, Természetvédelmi Hivatal. 2002, no. 1, 28 p. ISBN 963007168.

BOROS, E. 2010. Szikes vizeink jelentősége, kutatása és védelme: az MHT szikes vízi munkacsoportjának bemutatása. In MHT XXVIII. Sopron : Országos vándorgyúlés kiadványa, 2010.

BOZSÓ, G. - PÁL-MOLNÁR, E. - HETÉNYI, M. 2008. Relations of pH and mineral composition in salt-affected lacustrine profiles. In Cereal Research Communications, vol. 36, 2008, no. 5, pp. 1463-1466.

http://owww.met.hu/eghajlat/eghajlati_adatsorok/sz/Navig/Index2.htm visited on 21st of august 2014.

McBRIDE, M. C. 1994. Environmental chemistry of soils. New York: Oxford University Press, $1994.406 \mathrm{p}$.

NYIZSALOVSZKI, R. - SZABÓ, Sz. 2003. A talajvízszint mozgásának idő-és térbeli változásai egy hegylábi mintaterületen. In Földrajzi Értesítő, vol. 52, 2003, no. 1-2, p. 23-36.

PÁL-MOLNÁR, E. - BOZSÓ, G. 2007. Complex environmental geochemistry of saline lake sediments. In Cereal Research Communications, vol. 35, 2007, no. 2, pp. 889-892.

PÁLFAI, I. 1994. Összefoglaló tanulmány a Duna-Tisza közi talajvízszint-süllyedés okairól és a vízhiányos helyzet javításának lehetőségeiról. In Pálfai Imre (szerk.) (1994): A Duna-Tisza közi hátság vízgazdálkodási problémái. A Nagyalföld Alapítvány kötetei, Békéscsaba, 1994, no. 3, p. 111-123.

D'ODORICO, P. - BHATTACHAN, A. - DAVIS, K. F. - RAVI, S. - RUNYAN, Ch., W. 2013. Global desertification: Drivers and feedbacks. In Advances in Water Resources, 2013, no. 51, p. 326-344.

PÉCZELY, Gy. 2009. Éghajlattan. Szeged : Tankönyvkiadó, 2009. 280 p.

RAKONCZAI, J. - BÓDIS, K. 2002. A környezeti változások következményei az Alföld felszín alatti vízkészleteiben. In Jakucs László, a tudós, az ismeretterjesztó és a művész, 2002. p. 227-238.

RAKONCZAI, J. - BOZSÓ, G. - MARGÓCZI, K. - BARNA, Gy. - PÁL-MOLNÁR, E. 2008. Modification of salt-affected soils and their vegetation under the influence of climate change at the Szabadkígyós steppe (Hungary). In Cereal Research Communications, vol. 36, 2008, no. 5, pp. 2047-2050.

STANOVÁ, Š. - JANÁK, M. - RIPKA, J. 2008. Management of Natura 2000 habitats, Pannonic salt steppes and salt marshes. Directive $92 / 43 / \mathrm{EEC}$ on the conservation of natural habitats and of wild fauna and flora (1530). In Technical Report, 2008. 22 p. ISBN 978-92-79-08316-7.

SZILÁGYI, J. -VOROSMARTY, Ch. 1993. A Duna-Tisza közi talajvízszint-süllyedések okainak vizsgálata. In Vízügyi Közlemények, vol. 75, 1993, no. 3, p. 280-294.

TÓTH, T. 2005. Dynamics of salt accumulation in the Danube Valley. International salinity forum managing saline soils and water: science, technology and social issues Oral Presentation Abstracts, Riverside Convention Center, Riverside, California, USA, 25-28 April 2005. p. 449-452.

VÁRALLYAY, Gy. 1999. Salinization/alkalization/sodification processes in the Carpathian Basin. In Agrochemistry and Soil Science, vol. 48, 1999, no. 3-4, p. 399-418.

ZHANG, L. - FANG, J. - JOECKEL, R. M. 2013. Microbial biomass and community structurein alkaline lakes of the Nebraska Sand Hills, USA. In Chemical Geology, 2013, no. 356, p. 171-180.

SPECIAL THANKS to the ATIVIZIG (Alsó-Tisza-vidéki Vízügyi Igazgatóság) for the groundwater data of two wells.

\section{Contact address:}

László Halmos (MSc), University of Szeged, Faculty of Science and Informatics, Department of Mineralogy, Geochemistry and Petrology, H-6723 Szeged, Egyetem u. 2-6, e-mail: halmlaci@gmail.com, 疋 +36 62544 058, Fax: 36 62426479 